Abant Tıp Dergisi

Olgu Sunumu / Cilt 10 Sayı 2 YII 2021
Abant Medical Journal

Case Report / Volume 10 Issue 2 Year 2021

\title{
Adelilumab Tedavisinden Sonra Gelişen Bir Listeria Menenjiti: Olgu sunumu
}

Listeria Monocytogenes Meningitis Developed After Adalimumab Treatment in A Patient with

Ulcerative Colitis: A Case Report

PInar SIRMATEL BUCUK ${ }^{1}$ iD, Fatma SIRMATEL ${ }^{2}$ (D)

${ }^{1}$ Medical Faculty of Ege University, Izmir, Turkiye

${ }^{2}$ Bolu Medical Faculty of Abant Izzet Baysal University, Department of Infectious Diseases, Bolu, Turkiye

\section{Öz}

Son yıllarda, anti-inflamatuvar amaçlı kullanılan anti TNF- $\alpha$ ajanların tedavisi sırasında gelişen latent ve fırsatçı enfeksiyonlar hasta açısından önemlidir. Bu yazıda kronik ülseratif kolit olarak izlenen ve ilk doz adelimumab tedavisinden beş gün sonra gelişen bir L.monocytogenes menenjit olgusu sunuldu. Hastanın bakteriyi nereden aldığı tam olarak anlaşılamadı. Ancak L.monocytogenes'in normal insan barsak florasında bulunacağı ve bakteriyemisinde mortalitenin yüksek olduğu biliniyordu. Ülkemizden bildirilen, adalimumab kullanım sonucu gelişen, ilk listeria menenjit olgusunu sunmak istedik. Yaptığımız literatür taramasında kolitis ülseroza tedavisinde kullanılan adalimumab kullanımı sonucu gelişen L.monocytogenes enfeksiyonlarına ve anti TNF$\alpha$ ajanların yol açtığı yeni fırsatçı enfeksiyonlara dikkat çekmek istedik istedik.

Anahtar Kelimeler: Ülseratif kolit, anti TNF ilaçlar, listeria menenjiti.

\section{Abstract}

Latent and opportunistic infections that will develop during the treatment of anti TNF- $\alpha$ agents used for anti-inflammatory purposes in recent years are important for the patient. In this paper, a case of Listeria Monocytogenes (L.monocytogenes) related meningitis developing five days after the first dose of adalimumab treatment administered in a patient who was being followed up for ulcerative colitis is presented. It is not fully understood where the patient got the bacteria. However $L$. monocytogenes was known to be potentially found in gut normal flora of human body and the mortality of its bacteremia was known to be high. We wanted to present the first case of listeria meningitis reported from our country and developed as a result of adalimumab use. In the literature review we made in this presentation, we wanted to draw attention to L. monocytogenes infections and new opportunistic infections caused by anti TNF- $\alpha$ agents developed as a result of the treatment of adalimumab used in the treatment of colitis ulcerosa.

Keywords: Colitis ulcerosa, anti-TNF agent use, listeria meningitis.

\section{INTRODUCTION}

Listeria is a gram positive, intracellular, facultative anaerobe bacteria which is present in the intestine of humans and animals (1-5). It is a pathogen which goes with septicemia and meningitis in pregnant women, newborns, immunosuppressive patients and has a quite high mortality unless treated (6-8). Although listeria epidemics are not frequently seen in our country, this bacteria is known to be present in fruit juices, raw food, chicken, milk and dairy products like cheese $(1,5,9)$. While it causes fever and gastroenteritis in food contaminations, its mortality is not very high $(5,10,11)$. Listeria monocytogenes which has various subtypes and causes disease in only humans leads to severe infections due to immunosuppression in patients who use corticosteroids, chemotherapy and antiTNF- $\alpha$ agent $(2,12,13)$. Listeria monocytogenesrelated sepsis, meningitis, meningoencephalitis, cerebritis, rhomboencephalitis, and brain abscesses were reported as case reports in patients who had diabetes mellitus, cancer, cirrhosis, organ transplantation, collagenosis and chronic inflammatory bowel diseases $(3,7,14-$ 17). Our presentation case is a meningitis developing in the course of single dose adalimumab use, a TNF- $\alpha$ agent. This is the first case in our country. The patient was evaluated clinically, microbiologically and radiologically. 
The aim of the presentation is to pull attention to anti-TNF- $\alpha$-related L.monocytogenes infection and to discuss the case under the light of literature by reminding that it is an etiologic agent for meningitis difficult to diagnose.

\section{CASE REPORT}

A 42-year-old female patient who was diagnosed with ulcerative colitis for two years. She was treated some drugs (azathiopirine, deltacortil and salofalk) but not good results. The patient's treatment was changed adalimumab. She used first dose adalimumab due to exacerbation of ulcerative colitis. After five days single dose of 40 mg daily adalimumab-(HUMIRA) treatment she was admitted to another center with complaints of fever, headache and diarrhea 3-4 times daily. First time she was sent home after fluid resuscitation had been administered by her family doctor. But again she was admitted to emergency room due to high fever and continuing diarrhea and hospitalized with prediagnosis of balance disorder, double vision and altered conscious developing within the recent three days. She had permanent neck stiffness, fever (39.10 C), internal strabismus in the right eye and mild confusion on physical examination. Her blood pressure was 105/80 $\mathrm{mmHg}$, cardiac sounds were rhythmic (102 bpm), bowel sounds mildly increased. The aim of diagnosis applied to her, lumbar punction was performed after ocular fundus and nonenhanced cranial computed tomography (CT) examinations. Cerebral spinal fluid (CSF) pressure was elevated and appearance was xanthochromic. On CSF examination; protein was $188 \mathrm{mg} / \mathrm{dL}$, glucose $7 \mathrm{mg} / \mathrm{dL}$ (blood glucose 106 $\mathrm{mg} / \mathrm{dL}$ ), chloride $103 \mathrm{mmol} / \mathrm{L}$, LDH $260 \mathrm{U} / \mathrm{L}$, cell count $535 \mathrm{~mm} 3$ (80\% polymorph nuclear cells), gram positive bacilli were seen on gram staining. The other laboratory tests were as follows in her serum sample: white blood cells (WBC) count $8700 \mathrm{~mm} 3$, ALT $43 \mathrm{IU} / \mathrm{L}(\mathrm{n} .55)$, AST $40 \mathrm{IU} / \mathrm{L}(\mathrm{n} .35)$, LDH $382 \mathrm{U} / \mathrm{L}(\mathrm{n} .220)$, sodium $129 \mathrm{mmol} / \mathrm{L}$, urea 28 $\mathrm{mg} / \mathrm{dL}$, creatinine $0.73 \mathrm{mg} / \mathrm{dL}$, glucose 106 $\mathrm{mg} / \mathrm{DI}(\mathrm{n} .100), \quad$ CRP $187 \mathrm{mg} / \mathrm{l}(\mathrm{n} .0 .5) \quad$ and eryhrocyte sedimentation rate $112(\mathrm{~mm} / \mathrm{h})$. Abundant erythrocytes and leucocytes were seen on feces microscopy. Fecal parasite (entamoeba histolytica adhesion test and giardia) and viral antigen (rotavirus and adenovirus) tests were negative for feces and pathogen bacteria was not isolated on fecal culture. On her radiological tests, X-ray graphy was normal. Cranial magnetic resonance imaging (the diffusion-weighted MRI) showed a restricted diffusion area involvement size of $1.5 \times 1.1 \mathrm{~cm}$ reguler shape which is located on the left superior temporal gyruse (figure 1 ). Also cranial MRI revealed hyperintense lesions on T1A and nonspecific lesions in bilateral frontal deep white matter (figure 3). The abdominal ultrasonography and computed tomography revealed hypodense and milimetric lesions in the liver (figure 2). Serological tests observed respectively VDRL, anti HIV, $\mathrm{HBs} \mathrm{Ag}$, anti $\mathrm{HBs}$, anti $\mathrm{HBC}$ total and anti HCV tests were all negative, but anti HAV IgG, toxoplasmosis IgG, cytomegalovirus (CMV) IgG and herpes type 1 IgG were positive by EIA. Also monospot test was negative for EBV and ANA profiles were negative by IFA. Brucella antibody was negative in CSF and blood by standard tube agglutination. First time patient was treated as acute bacterial meningitis with intravenous $2 \times 2$ gr daily ceftriaxone for two days. Fever continued in the follow-up. Subsequently the treatment was changed to ampicilline ( $4 \times 3$ gr daily IV) plus co-trimoxazole (trimethoprim sulfamethoxazole $800 / 160 \mathrm{mg}$ daily PO) because overgrowth L.monocytogenes in cerebral spinal fluid and blood cultures. Her fever decreased on five days of treatment and parenteral antibiotics continued for 3 weeks and peroral antibiotics continued for two weeks. She was followed up for two months without any complications. She was referred to gastroenterology clinic for treatment of ulcerative colitis after she had fully recovered from listeriosis. 


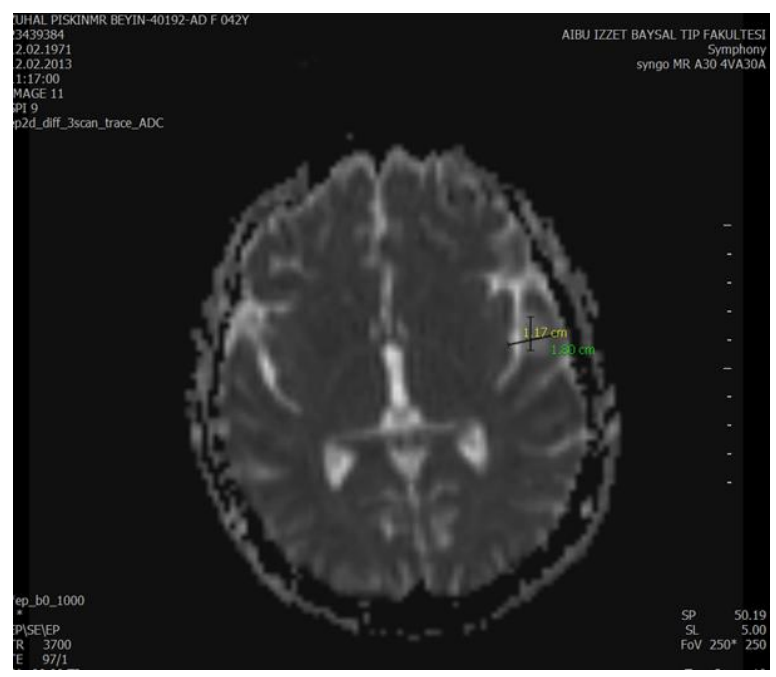

Figure 1. Diffusion-weighted MRI showed a restricted diffusion area involment size of $1.5 \times 1.1 \mathrm{~cm}$ reguler shape which is located on the left superior temporal gyruse.

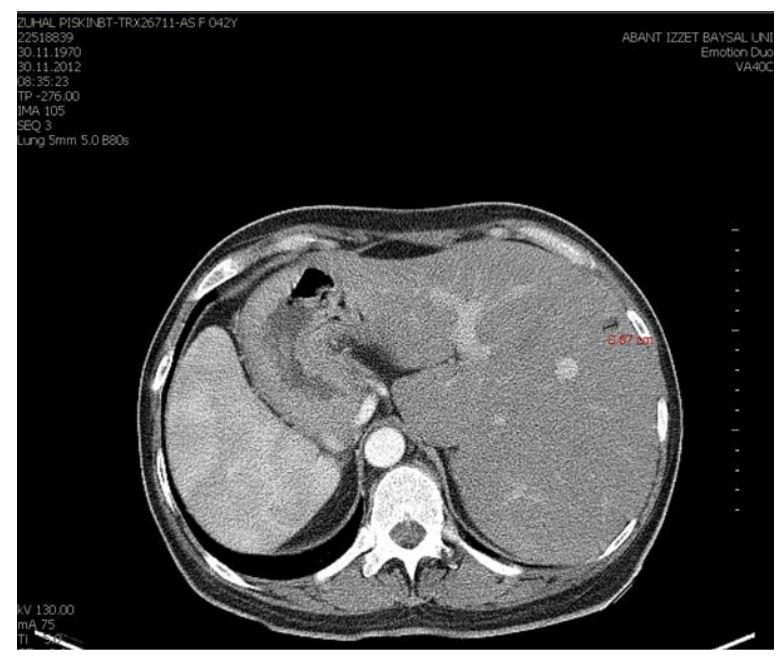

Figure 2. The abdominal computed tomography and ultrasonography revealed hypodense and milimetric lesions in the liver.

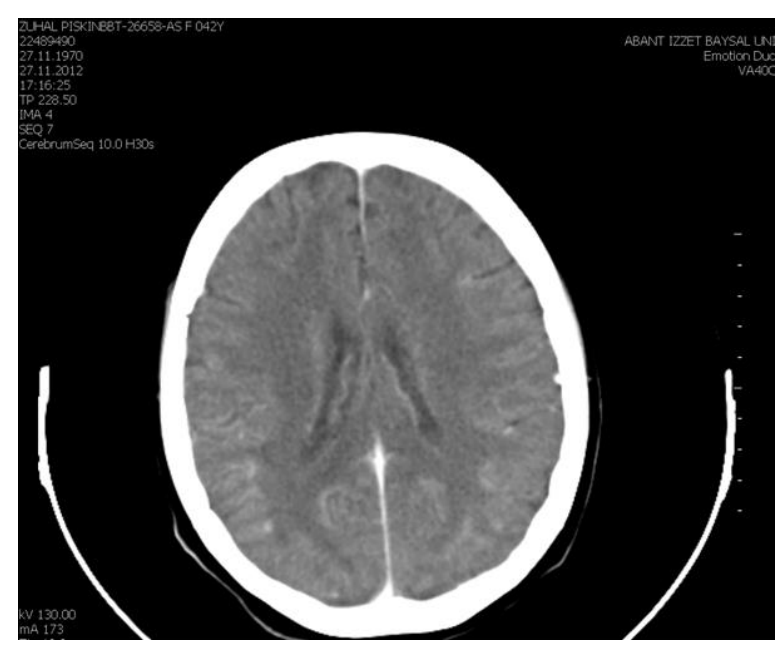

Figure 3. Following later cranial magnetic resonance imaging (MRI) revealed hyperintense lesions on T1A and nonspecific lesions in bilateral parietal deep white matter.

\section{DISCUSSION}

Immunosuppressive agents used in inflammatory bowel diseases but it make to the patients susceptible to many bacterial infections such as listeria and tuberculosis $(10,11,18,19)$. Opportunistic and latent infections are known to be life-threatening in patients who receive human-derived homologous anti TNF- $\alpha$ medications which are frequently used in recent years and the patients are recommended to be evaluated for tuberculosis, chronic viral hepatitis before using these agents $(7,10)$. L.monocytogenes which is an intracellular microorganism causes bacteremia by rapidly spreading to circulation from intestinal mucosa due to impaired phagocytosis functions (5). The action of human-derived anti TNF- $\alpha$ agents is to prevent inflammation through causing apoptosis, namely to impair the function of monocytes, macrophages and $T$ cells which play a role in inflammatory response (10). Tobon GJ 2007 et all (11). Reported that they lost a L.monocytogenesrelated meningitis patient with SLE due to delayed treatment. A total of 174 systemic lupus erythematosus (SLE) patients were followed up after receiving infliximab treatment, an anti TNF$\alpha$ agent and listeria meningitis was detected in five female patients and all were treated with high dose ampicillin(13). L.monocytogenes infection was found 2-3 fold greater in infliximab and adalimumab use in animal tests $(17,20)$. L.monocytogenes-related sepsis and meningitis cases were reported after a short while following infliximab and adalimumab use particularly in the patients with inflammatory bowel diseases such as ulcerative colitis and Crohn's disease (7). The clinical condition was mortal in $33-50 \%$ of sepsis and meningitis cases if not diagnosis quickly. In this case should be changed treatment to high dose ampicillin (8-12 gr daily) because it was lifesaving $(5,20,21)$. L.monocytogenes-related meningitis cases have been reported as case reports in ulcerative colitis/Crohn's disease patients using infliximab $(8,15,16)$. 
L.monocytogenes infection was seen in a total of 38 SLE cases who were receiving anti TNF- $\alpha$ agents and 26 of them were reported (3). In a review of Tobon GJ 2007 et al. seven patients with SLE and L.monocytogenes infection died despite a proper treatment. Ampicillin, cotrimoxazole, gentamycin treatment should be used in combination for a long time for treatment of L.monocytogenes infection. High dose ampicillin and aminoglycoside combination provided better results in the studies reporting 24-62\% mortality in listeria meningitis (5). Bautista JM et all (2) were presented three patients with inflammatory bowel disease patients had positive L.monocytogenes infection one patient's death. High dose ampicillin and gentamycin combination was used in treatment of L.monocytogenes meningitis reported from our country $(5,9,21)$ In the presented case, we used ampicillin and co-trimoxazole combination for four weeks and provided a good result. The authors who reported that healthy individuals excreted the bacteria with feces in the ratio of 1 $62 \%$ and this ratio could be as high as $77 \%$ in laboratory workers pulled attention to L.monocytogenes-related sepsis and meningitis development in use of anti TNF- $\alpha$ agents $(18,22)$. It could not be clearly understood from where our patient could get the bacteria. The bacteria could have been activated in the intestine due to adalimumab treatment and lead to sepsis and meningitis thereafter $(4,17)$. Because it is reported that the incidence of opportunistic infections could be higher five days after anti TNF- $\alpha$ use. In our case, diarrhea started five days after the first dose of adalimumab treatment and fever and meningitis developed thereafter. Listeriosis was reported to be detected in high doses in cheese in our region (1). Although our patient was using pasteurized cheese, we estimated that this bacteria became activated when it was colonized after adalimumab treatment.

CSF findings and clinical condition of the patient are quite variable in L.monocytogenes meningitis
$(2,14)$. High fever and signs of central nervous system involvement (neck stiffness, Kernig's and Brudzinski's sign) are the most important findings, as in our case. Hyponatremia is typical beside the typical laboratory findings of acute bacterial meningitis, as in our case. Because one reported that detected hyponatremia and seen high ratio seen as $86 \%$ in L.monocytogenes meningitis (14). In addition, L.monocytogenes should be kept in mind in immunosupressive patients who do not respond to antibiotic treatment and bacteria could not be isolated. In a long standing L.monocytogenes infection serial, four meningitis, five sepsis cases were detected and immunosupression was shown as the precipitating factor in all of them (5). In this review reported from Kayseri that risk factors like cirrhosis, diabetes mellitus, hematologic diseases and malignity were shown as precipitating factors for L.monocytogenes infections (5).

In addition, mortality was reported to be more frequent in meningitis than in sepsis $(5,14,21)$. The bacteria was reported to easily reach central nervous system and cause meningitis particularly in the immuno-compromised individuals $(14,22)$. High fever and central nervous system involvement findings such as stiff neck, Kernig's and Brudzinski's signs are the most important findings as in our case. Definite diagnosis is made by the isolation of the bacteria in blood and CSF. Empirical treatment was changed high dose ampicilline then seen based on the culture isolation, as in our case. The patient had to xanthochromic appearance of CSF, presence of strabismus and detection of gram positive bacilli may the examples of different manifestation of listeria meningitis. Cranial nerve involvement and cerebral abscesses cause increased mortality in listeria meningitis $(14,21,22)$. Early diagnosis and treatment prevented mortality in our case. Our patient who was found to be the first case in our country and third case in literature as the result of screening in Pubmed, Cochrane and Google developed meningitis after adalimumab treatment. Early isolation of the bacteria and 
changing to the treatment positively affected the prognosis. Inadequate and improper antibiotic treatments lead to recurrence or widespread cerebral abscesses $(10,16)$. We recommend enhanced MRI with contrast in all patients with listerial meningitis, patients with listerial bacteremia and central nervous system signs or symptoms, and patients suspected of having intracranial listeriosis.

\section{CONCLUSION}

Considering listeria meningitis may positively affect prognosis in meningitis cases that the bacteria could not be isolated and in presence of unresponsiveness to treatment. L.monocytogenesis which is one of the bacterial infections which cause acute gastroenteritis and may rapidly cause sepsis should always be kept in mind during treatment with anti- TNF- $\alpha$ agents used in chronic inflammatory bowel diseases like Cohn's disease and ulcerative colitis. During recent years an increasing number of Listeria meningitis in patients with ulcerative colitis under treatment with infliximab, adalimumab, azathioprine and corticosteroids has been described $(2,22)$. Clinicians should be aware of the possibility of meningitis due to $L$. monocytogenes in patients with ulcerative colitis on immunosuppressive and corticosteroids $(7,10)$.

Thanks to Dr. Sirmatel O, Korkmaz T and Gunes O for helping.

Informed Consent: Written consent was obtained from the participants.

Conflict of Interest: Authors declared no conflict of interest.

Financial Disclosure: Authors declared no financial support.

\section{REFERENCES}

1. Ertem E. Listeriosis. Turkiye Klin J Int Med Sci. 2006;2(28):100-5.

2. Miranda-Bautista J, Padilla-Suárez C, Bouza E, Muñoz P, Menchén L, Marín-Jiménez I. Listeria monocytogenes infection in inflammatory bowel disease patients. Eur J Gastroenterol Hepatol. 2014;26(11):1247-52.

3. Horta-Baas G, Guerrero-Soto O, Barile-Fabris L. Central Nervous System Infection by Listeria monocytogenes in Patients With Systemic Lupus Erythematosus: Analysis of 26 Cases, Including the Report of a New Case. Reumatol Clínica (English Ed. 2013;9(6):340-7.

4. Gil C, Legido J, Cuenca C, Santamaría A, Sacristán MV, Salvatierra $C$, et al. Meningitis por Listeria monocytogenes durante tratamiento con adalimumab. Gastroenterol Hepatol. 2009;32(8):587-8.

5. Yildiz O., Aygen B., Esel D., Kayabas O., Alp E. SB. sepsis and meningitis due to listeria monocytogenes. Yonsei Med J. 2007;48(3):433-8.

6. Dzupova O, Rozsypal H, Smiskova D, Benes J. Listeria monocytogenes meningitis in adults: The Czech Republic experience. Biomed Res Int. 2013;2013.

7. Horigome R, Sato H, Honma T, Terai S. Septicemic listeriosis during adalimumab- and golimumab-based treatment for ulcerative colitis: case presentation and literature review. Clin J Gastroenterol. 2020;13(1):225.

8. Thussu A LS. Successful Treatment of Listeria Meningitis in a Pregnant Woman with Ulcerative Colitis Receiving Infliximab. Gen Med Open Access. 2013;01(03):1-3.

9. Vardar I., Yurtsever SG., Coskun NA., Kaptan F., El S. US. Meningitis due to Listeria monocytogenes: case report. ANKEM Derg. 2011;25(1):54-7.

10. Bonovas S, Pantavou K, Evripidou D, Bastiampillai AJ, Nikolopoulos GK, Peyrin-Biroulet L, et al. Safety of biological therapies in ulcerative colitis: An umbrella review of meta-analyses. Best Pract Res Clin Gastroenterol. 2018;32-33:43-7.

11. Tobón GJ, Serna MJ, Cañas CA. Listeria monocytogenes infection in patients with systemic lupus erythematosus. Clin Rheumatol. 2013;32(SUPPL. 1):25-7.

12. Lee $\mathrm{MC}, \mathrm{Wu} \mathrm{YK}$, Chen $\mathrm{CH}, \mathrm{Wu} \mathrm{TW}$, Lee $\mathrm{CH}$. Listeria monocytogenes meningitis in a young woman with systemic lupus erythematosus. Rheumatol Int. 2011;31(4):555-7.

13. Issa IA EA. Listeria Meningitis After Infliximab in Ulcerative Colitis: Does the Risk of Treatment Outweigh the Benefit. Br J Med Med Res. 2013;3(4):2008-16.

14. Brouwer MC, Beek D Van De, Heckenberg SGB, Spanjaard L, Gans J De. community-acquired listeria monocytogene meningitis in adults. 2006;(October):1233-8.

15. Williams $G$, Khan AA, Schweiger F. Listeria meningitis complicating infliximab treatment for Crohn's disease. Can J Infect Dis Med Microbiol. 2005;16(5):289-92.

16. Rana F, Shaikh MM, Bowles J. Listeria meningitis and resultant symptomatic hydrocephalus complicating infliximab treatment for ulcerative colitis. JRSM Open. 
2014;5(3):205427041452222.

17. Angelison L, Almer S, Davidsdottir L, Hammarlund $P$, Lindgren $S$, Hindorf $U$, et al. Short and long-term efficacy of adalimumab in ulcerative colitis: a real-life study. Scand J Gastroenterol. 2020;55(2):154-62.

18. Ali T, Bronze, Kaitha, Mahmood, Ftaisi, Stone. Clinical use of anti-TNF therapy and increased risk of infections. Drug Healthc Patient Saf. 2013;79.

19. Ali t., Kaitha S., Mahmood S, Ftesii A., Stone J. BM. Clinical use of anti-TNF therapy and increased risk of infections. Drug Healthc Patient Saf. 2013;79.

20. Zhang $\mathrm{Y}$, Zang G-Q, Tang Z-H, Yu Y-S. Listeria monocytogenes meningitis in an immunocompetent adult: a case report. Rev Soc Bras Med Trop. 2012;45(3):410-1.

21. Erdem H, Kilic S, Coskun O, Ersoy Y, Cagatay A, Onguru $P$, et al. Community-acquired acute bacterial meningitis in the elderly in Turkey. Clin Microbiol Infect. 2010;16(8):1223-9.

22. Bodro $M$, Paterson DL. Listeriosis in patients receiving biologic therapies. Eur J Clin Microbiol Infect Dis. 2013;32(9):1225-30. 